\title{
The Growth of Korean Companies and Their Contributions to the Miracle of the Han River
}

\author{
Phuoc Cuu Long Le ${ }^{1}$, Jong Ik Kim ${ }^{2}$ and Kunbae Kim ${ }^{*}$ \\ ${ }^{123}$ College of Business, Soongsil University, Seoul, Korea \\ ${ }^{1}$ lpclong@gmail.com, ${ }^{2}$ gasplus@daum.net, ${ }^{3}$ kbkim@ssu.ac.kr
}

\begin{abstract}
Over the past six decades, the Korean economy has witnessed remarkable growth. In the 1950s, when the government was first established, Korea was the one of the poorest countries in the world. Now, it has grown as a global economic power with a solid industrial base. Korea's economic success since then has been named "the Miracle of the Han River". Along with the growth of the economy, there is an enormous contribution from Korean companies which probably started from small shops and have grown to become global giants. There are some studies about the Korean economy and Korean companies, especially Chaebols. These studies mainly focus on the relationship between value and ownership structure, and the gap between controlling power and cash flow ownership. However, there is a controversy over how the companies have contributed to the success of the Korean economy. These critical issues have attracted the attention of not only academic scholars but also policy makers. This study aims to present the outstanding post-war development of the Korean economy with a particular concentrate on the role played by Korean companies. First, the growth of Korea economy is reviewed. Second, we cover the growth of Korean firms, which have contributed remarkably to the national economic development. Third, we provide an overview of government policy and the external environment facing Korean firms, and discuss about the intervention of government in business activities that lead to industrialization. Fourth, we show how Korean businessmen have carried out business activities in conjunction with the government-directed economic policies. Findings from this study highlight many implications for the developing countries and their business sector.
\end{abstract}

Keywords: Korean companies; Chaebol; Korean economic development; Market economy; Government policy; HCIs; Industrialization; Globalization; SME.

\section{Introduction}

In the 1950s, Korea was one of the poorest nations in the world with an income per capita about $80 \mathrm{USD} / \mathrm{year}$ and government's expenditures mainly belong to foreign aids. After half of development century, Korea has expanded sharply in an economy with averaged economic growth annually about 7,6\% and kept continuing in 40 years made that was called as "The Miracle of the Han River". Whereby, in the early of 1990s, Korea has become one of the four Asian Economic Dragons. So what made a big change for Korea's economy in just only about 60 years? Korea has achieved accelerated economic growth and social climb. Per capita income grew from 1,342 dollars in 1960 to 19,227 USD in 2008. At the end of 2011, per capita income of Korea was about 31.750 USD more than EU was 31.550 USD, turnover reached over 1.080 billion dollars, ranked in 8th in the world regarding export [4]. ${ }^{1}$

With those rapid changes, from a poor and primarily get foreign aids country, Korea is the only one country that developed successfully in the short time and became an example for many developing countries to catch up with an advanced economy [4]. Korean

\footnotetext{
${ }^{1}$ Kunbae Kim is Professor of Marketing department, College of Business, Soongsil University, Seoul. Korea. $\mathrm{He}$ is also a senior consultant of CJ, Lotte, LG, Samsung etc. His interest and recent works are new product development, Concept creation, Marketing research, Concept Engineering and Advertising.
} 
economic development has been achieved by the leadership under the capitalism, economic system where private proprietorship is insured and the government's aggressive economic policies. Korea has achieved both democratization and industrialization in a short period [4]. Along with its growth, there is a huge contribution from the companies, organizations which probably started from a small shop and has grown to the global giants such as Samsung, Hyundai. Samsung started as a small trading company and became a leading global player in electronics and semiconductor industry. Hyundai, which started as a rice retail shop and then became a leading global player in automotive and shipbuilding industry [3].

There has been a proceeding controversy about the points beyond its success, which has attracted the attention of not only academic scholars but also policy practitioners. Hence, an attentive research of Korea's economic growth and its company developments is necessary. Thus, there are some main points of this study. First, this study, review six decades' development of the Korean economy. Second, we cover Korean companies, especially Chaebols which have contributed to the economic development. Third, we mention the intervention of government in business activities to lead the industrialization by overviewing the government policy and external environment facing the Korean firms. Finally, we discuss how Korean businessmen have carried out business activities in conjunction with the government-directed economic policies.

\section{Building the Foundation for Market Economy (1945-1960)}

Korea was left in complete economic disorder after the liberation from Japan in 1945, then had been controlled by the American military government until 1948. The market economy system was established by privatizing the confiscated Japanese factories and enterprises properties. After the Korean war in 1953, Korea experienced extreme political, social, economic disruption and underwent economic reconstruction after the Korean war. Korean firms sold relief goods from U.S such as cotton, wool, sugar, food and participated in the reconstruction project. Trading business was a major industry in this period. Manufacturing industry was not developed yet since there was not enough technology and market demand [2]. Major government economic policies as follow:

(*) Establishment of Private Property Ownership and Market Economy

(*) Reform to Privatize the Confiscated Enemy properties

(*) Agricultural Land Reform

(*) Disposal of U. S. Aid

\subsection{New Ownership of the Confiscated Properties}

The government established the Private Property Ownership and free market system as the supreme principle of economy. Korean economic growth may be founded on a strong commitment to people and the government to free enterprise and market system. Though the government adopted an extensive intervention policy, it also took the various measures to nurture private business. Government and private enterprise worked together for economic development. [4]

The confiscated Japanese-owned property was sold by the military government and they tried to maintain the same policy to privatize the confiscated Japanese properties. The government insisted that the experienced managerial staff such as the former employees of the confiscated companies should take over. As the Congress suggested, the landlords were forced to sell their farmland to the government and new independent farmer according to the agricultural land reform. Korean government maintained the priority given to the leading manager or the former employees. The ownership was given to the former employees of the confiscated companies or the businessmen who worked in the same line of business. [4]

\subsection{Business Growth from U. S. Aid and Reconstruction}

After the Korean war, the foreign aid not only contributed significantly to resolving 
the severe shortage of raw materials and capital goods but also provided an opportunity for the Korean firms to conduct their business activities and accumulate capital, especially U.S aid. Korea received $\$ 3.137$ million in U.S aid during 1945-1961. The profits collected in the industries based upon foreign aids were used for speculative intention or, went to curb market. During the War, there were prosperous businesses of military goods engaged in the procurement for the UN Armed forces. Many other construction companies participated in the reconstruction projects of the Korean economy after the war, and this also paved the way to going to overseas construction market later. [4]

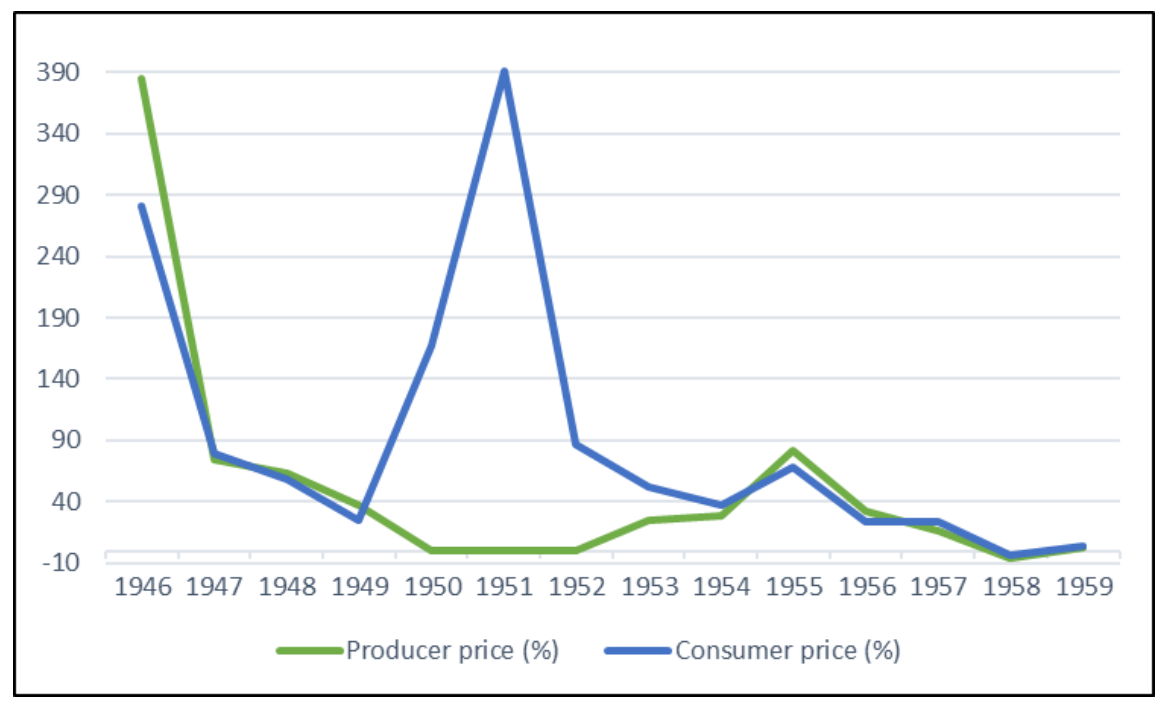

Figure 1. Price Inflation from 1946 to 1959

\subsection{Business Growth from Trading Business}

At this time, Korea depended on the import of necessary products, therefore trading was a major industry. Foreign trade began gradually to expand business activities, and when a large-scale trade was undertaken under governmental order to reconstruct the Korean economy destroyed by the war, trade partners were expanded to the United States and Western Europe. The pattern of trade shifted to agency from barter trade and the government encouraged imports through special loans of foreign exchange and subsidies in order to resolve the shortage of goods. Many businessmen accumulated capital and laid a foundation by learning business practices. Many Korean firms grew by diversifying into many areas. Hence, the diversified companies from the parent companies were interconnected as Korean-style conglomerate called "Chaebol". The trading companies would gradually become the center of each Chaebol due to the export-oriented growth strategy of government. It played an important role that ordered and controlled all affiliated companies under Chaebol. [4]

They could make substantial contributions to their Chaebol's accumulation of capital through the gains from the allocation of foreign exchange at a lower rate (import quota) which was the primary source of capital accumulation of Chaebol. The representative trading companies at the time were Samho Trading, Dongah Sangsa, Bando Sangsa (LG), Dachan Sanup and Hwashin Sanup. Samsung started as a small retail shop in 1938. The founder, Lee Byungchul established Samsung Mulsan in 1948 to be involved in foreign trade. This company led business in Rhee's government. Samsung established Cheil Jedang, sugar and food company in 1953 and Cheil Wool \& Textile in 1954. Samsung has grown into the largest business group in Korea, with $\$ 227.3$ billion in revenue and 315,000 workers worldwide in 2010. The group's highly varied businesses span a broad range of industries, including electronics and semi-conductor, financial services, 
information technology, shipbuilding, and chemicals. The trading company of Chaebol was transformed into the General Trading Company representing each Chaebol. It was established to promote and coordinate the diversified trading business of Chaebol in the mid-1970s.

\section{Government directed Economic Growth (1961-1980)}

In 1961, through a military coup, the new government came to power. The government object was to fight poverty through economic development. Many businessmen were jailed just after the military coup. They were freed after the leader of businessmen and the chairman of Samsung met General Park and vowed to contribute to the economic development.

Government intervention in business activities was prevalent through this period. Government-directed growth strategy focused on promoting export of labor-intensive goods and later on building heavy and chemical industries. Major government economic policies as follow:

(*) The first five-year economic plan

(*) The financial, fiscal, and trade incentives policy for export promotion.

(*) The second five-year economic plan

(*) HCI Drive Plan

(*) Establishment of General Trading Company System:

(*) Industrial Adjustment Plan

\subsection{Export Oriented Business Growth}

During this period, the government accepted the businessmen as a partner in economic development, shared the goal of national development and created a good condition to activate the growth of their business. The government performed a mass of policies such as, establishing the economic planning board (EPB), nationalizing major commercial banks, creating a government-owned special bank. They controlled the central bank, established so-called policy financing system, which was a government-directed credit rationing system. Many successful firms grew out of export business, heavy, chemical industries; actively took advantage of the special demand from Vietnam and the middle east construction boom as a momentum for their growth. [4]

Korean economy suffered deficiency in most natural resources; the Korean domestic market was too small for efficient production of many items, but it had abundant and inexpensive labor that led the government to adopt an outward-looking development strategy. Therefore, the government decided to promote export based on the development of labor-intensive industries to achieve initial economic growth. They provided various incentive policies for export promotion, and these incentive policies contributed to the expansion of export business activities and size of export firms through capital accumulation and innovation [6]. For breaking through the outbreak of the Middle East War and the oil crisis in the mid-1970s, the government established a general trading company system whose purpose was to increase the economies of scale of the expansion into overseas markets and to reduce the transaction cost of diverse export items through efficient marketing activities. The general trading company coordinated the export activities of the affiliated companies of the business group and made it easier to possess greater entrance to preferential policy loans, hire a high-quality workforce, and flexibly switch any management's know-how to new business opportunities. A key factor to the success of the Korean firm was the close relationship with government. [6] 


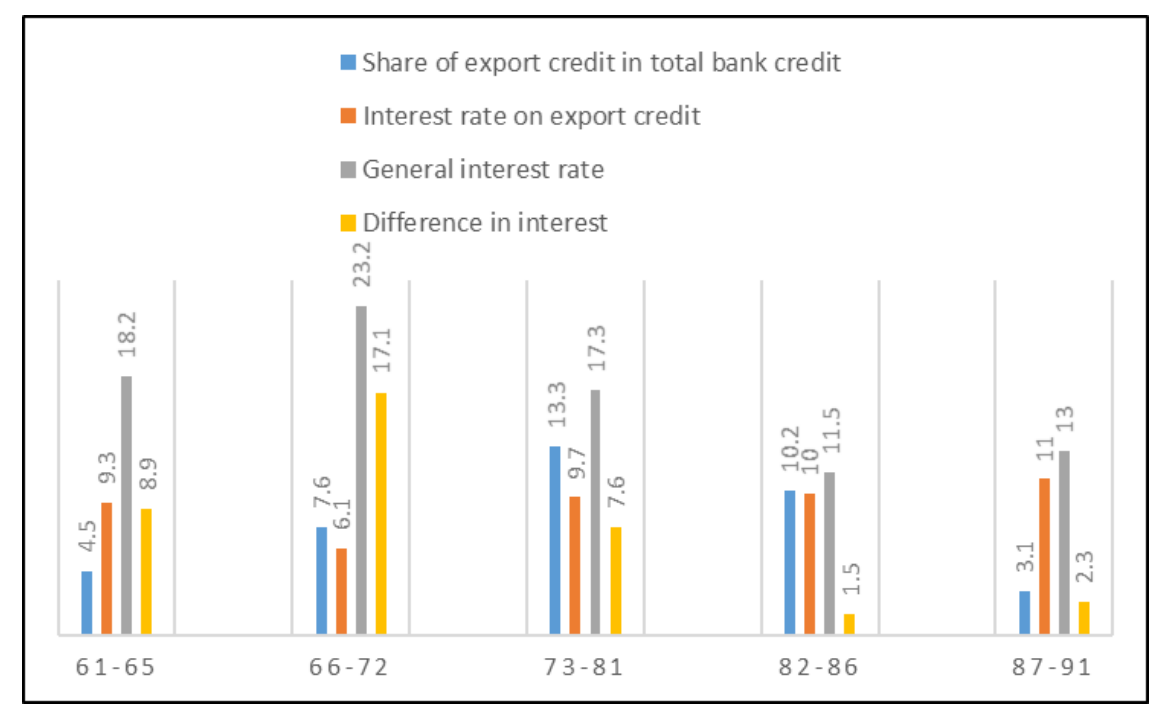

Figure 2. Export Credit by Bank

\subsection{Business Growth from the Heavy and Chemical Industry}

In the second part of the 1960s, the government encouraged the formation of the large firms to promote international competitiveness by utilizing the scale of economies in the heavy and petrochemical industry in the second five-year development plan. Main reason for this shift from labor-intensive growth was the increasing protectionism for laborintensive products in developed countries. A full-scale drive toward HCI began in 1973. The target of Korean government was 10 billion dollars of annual export by the early 1980s and the portion of HCIs in total exports would be lifted up well over fifty percent. Thus, six strategic industries were selected, which were non-ferrous metal, shipbuilding, chemical engineering, steel, machinery, and electronics. The government provided bank credit at preferential rates, foreign loans guaranteed by the government, and tax incentives. The government also provided opportunities for the giant firms to accumulate their capital and management skills rapidly, and to expand the size of their firms. While reinforcing incentives for HCIs, export incentives were gradually reduced. Many companies successfully laid their foundation and expanded thereafter [4], [6]. The brief description of how the representative company started in each industry is given as follow:

Steel Industry. In the first five-year plan, the government planned to build a 300,000 tons' steel plant and tried to get financial assistance from the World Bank. With diplomatic normalization with Japan in 1965, the government got a long term loan and the reparation fund from Japan then began to construct 1,000,000 tons' steel plant in Pohang in April 1970 and completed in July 1973. That is Pohang Steel Company (POSCO), which has grown into the largest steel plant in the world. [4], [6]

Automobile Industry. The automotive industry started under Park's government. The Saenara automobile company was established in 1962 by a Korean resident in Japan and started with semi-knocked-down (SKD) assembly production. From 1966, the policy was shifted to completely knocked down (CKD) to promote domestic production of parts and components. A variety of incentives were provided to accelerate the localization of parts and components the goal of which was completed domestic manufacturer of automobiles in Korea. Hyundai Motor Company was established in 1967 and produced Cortina in technological license from British Ford in 1968. Then, they were forced to build an original model on their own by hiring the retired English engineers and managed to acquire the technical assistance and bring the engine and transmission from the Mitsubishi motor in Japan. In 1976, Hyundai started to mass produce Pony, the first Korean passenger car and Korea became the 16th nation in the world to possess automobile model. In 1986, Hyundai exported to the U.S. market successfully, and Hyundai itself grew to one of the major players in the automobile industry. [4] 
Electronic Industry. The Korean electronics industry started its development earlier than other industries on the HCI sector because it had begun with labor-intensive assembly production. The government realized the great potential of the electronics industry as an export industry as a strategic export industry to be promoted. Samsung Electronics was established in 1969 and has grown into the flagship company of Samsung business group and eventually emerges as the strongest player as its bold and aggressive in semi-conductor industry in the 1990s. Daewoo Group also joined the electronics industry by setting up Daewoo Electronics in 1973. [4]

Shipbuilding Industry. Korean shipbuilding industry started in the 1960s, but the scale and size were not significant until Hyundai Heavy Industry (HHI) was established in 1974. It absorbed many technologies and developed its own at the point of production by integrating the various multi-national technologies. It learned the product design technology from Japan Kawasaki Heavy Industry and Denmark's Odense Steel Shipyard with the block building technology. Encouraged by the Hyundai's success, other business groups entered shipbuilding industry. Follow that, and HCIs took a significant share of production with export volume is $9.2 \%$ in 1964 and up to $42 \%$ in 1980. [4]

Table 1. Proportion of HCls in Production and Export from 1964 to 1980

\begin{tabular}{|l|l|c|c|c|c|c|c|c|}
\hline & & $\mathbf{1 9 6 4}$ & $\mathbf{1 9 7 0}$ & $\mathbf{1 9 7 2}$ & $\mathbf{1 9 7 4}$ & $\mathbf{1 9 7 6}$ & $\mathbf{1 9 7 8}$ & $\mathbf{1 9 8 0}$ \\
\hline \multirow{2}{*}{ Production } & HCI/GDP & $4.7 \%$ & $8.2 \%$ & $8.2 \%$ & $12.8 \%$ & $13.5 \%$ & $14.2 \%$ & $15.1 \%$ \\
\cline { 2 - 9 } & HCI/Manufact. & 30.4 & 39.2 & 37.0 & 49.9 & 49.3 & 53.2 & 53.6 \\
\hline \multirow{2}{*}{ Export } & HCI/Total & 9.2 & 12.8 & 21.3 & 32.5 & 29.8 & 35.4 & 41.8 \\
\cline { 2 - 9 } & HCI/Manufact. & 16.9 & 15.5 & 24.2 & 37.5 & 34.0 & 41.6 & 47.4 \\
\hline
\end{tabular}

\section{Adjustment and Shift to Globalization (1980-1997)}

The government attempted a drastic change in policy directions at the turn of the 1980s. The "consolidating growth on the basis of stability" replaced a "growth-first" strategy. "Private sector-led" rather than "Government-led" growth was emphasized. Major government economic policies as follow:

(*) Industrial Adjustment Plan

(*) Industrial Rationalization Program

(*) The Fair Trade Law Implemented

(*) Establishment of New labor-management Relations

(*) Market-friendly Development Policy

(*) Liberalization and Globalization Policy

\subsection{Business Reorganization by Structural Adjustment}

In the 1980s, the Korean government attempted a drastic change in policy directions. They tried to restore market-friendly development policies, and this was a big turnaround in the Korean economy. The government had stopped providing policy loans to private firms, and interest differential was eliminated [5].

This period witnessed the end of the cold war and Korean firms attacked the newly opened markets. The political democratization faced Korean firms with free competition in the market and new labor-management relationship. Also de-concentration of economic power wealth became a grave issue in a nation and the fair trade and anti-trust laws were enforced in 1981 were strengthened. Three rounds of investment coordination were initiated in 1979 and completed them by 1983. The government forced these firms to combine into the recently established Korea Heavy Industrial Company and coordinated automobile manufacturers to specialize their production in a specific type of vehicle to attain economies of scale. The government also provided rescue package, including loans 
from state-controlled banks to the troubled companies and thus restructured. The government-directed restructuring accelerated the concentration of economic power since a small number of Chaebols could take over the troubled companies. Despite its effort to rescue, HCIs had difficulties continuously up to the mid-1980s. Then, the government introduced market development act to initiate industrial rationalization.

In 1984-1987, two major ailing industries were rationalized. It included the reduction of many companies through combinations to cut their shipping capability or calling off deficit ridden overseas construction projects. The government lowered taxes and financial burdens of rationalized companies. The five diminishing industries (Ferro-alloys, textiles, fertilizer, dyeing and footwear) and four combining industries (diesel engines, automobiles, heavy construction equipment and heavy electrical equipment) were included in the rationalization program. [2]

The government's protective and preferential treatment created many advantages for insolvent companies. In additions, the insolvent firms were mostly taken over by Chaebols. It worsened the concentration of wealth as a result. In 1986, the government liquidated 54 bankrupt firms through the industrial rationalization program. The Chaebols that had taken over the insolvent firms received special loans from the bank to normalize these companies. [6] Through the structural adjustment, the geography of business had changed, and many Chaebol such as Samho and Kukje collapsed. Hyundai, Daewoo, and Samsung strengthened their position in this adjustment period. Korean firms regained their stability gradually since they had a favorable opportunity due to the so-called threelow phenomenon such as small petroleum price, low international interest rate, and low exchange rates. The Korean won decreased in value against the U.S dollar about $21 \%$. Korea's international competitiveness improved and enabled an increase in exports to an average growth rate of $31 \%$. Korea enjoyed an unprecedented surplus in the current account during 1986-1988 [4].

\subsection{Business Growth through Globalization}

The Korean economy met entirely different environment after the declaration of democratization in 1987. This democratization provided a significant impact on the Korean economy. Labor movement erupted like an active volcano. The labor force engaged in labor disputes and strikes to improve wage rates, shorten work hours and improve working conditions. Thus, wage rates and labor disputes increased rapidly as a result. The wage hike coupled with drastic appreciation of won brought about reducing economic growth. Business was faced with new labor-management relations. Fortunately, the external environment was favorable to the Korean economy. Soviet bloc collapsed, and China opened their market. Korean firms have access to newly opened market. The Korean firms faced the global growth era by taking this advantage. Thus, the Korean firms could resolve labor through wage hikes, the improvement of working conditions and shortening of work hours and gradually restore stability. [3], [4]

A big push toward globalization came in the early 1990s when the new government came to power. The new government realized that completed market opening was inevitable in the face of the globalization movement around the world. Multilateral negotiations were continuously engaged in order to escape from the probable increasing of protective retaliation. As a result, the WTO system, replacing the GATT system was created. The globalization and liberalization as a top policy. The new government undertook a number of reform measurements aimed at deregulation and liberalization. Additionally, the government statement to liberalize and globalize economy forced a big firm chose to globalize its business. The year 1990 could be marked as the starting year of globalization in that Korea's overseas direct investment exceeded its capital inflow. [4] 
Table 2. Major Macroeconomic Indicators (1980-1990)

\begin{tabular}{|c|c|c|c|c|c|c|c|c|c|c|c|}
\hline \multirow{3}{*}{ Years } & \multirow{2}{*}{\multicolumn{2}{|c|}{$\begin{array}{c}\text { M2 } \\
\text { (end of year }\end{array}$}} & \multicolumn{7}{|c|}{ Consolidated central goverment } & \multirow{3}{*}{$\begin{array}{l}\text { Unemploy- } \\
\text { ment rate }\end{array}$} & \multirow{3}{*}{$\begin{array}{c}\text { Consumer } \\
\text { price } \\
\text { inflation }\end{array}$} \\
\hline & & & \multirow{2}{*}{$\begin{array}{c}\begin{array}{c}\text { Fiscal } \\
\text { balance }\end{array} \\
\% \text { of } \\
\text { GDP }\end{array}$} & \multicolumn{3}{|c|}{$\begin{array}{c}\text { Expenditure and net } \\
\text { lending }\end{array}$} & \multicolumn{3}{|c|}{ Revenue } & & \\
\hline & $\begin{array}{c}\text { Nominal } \\
\text { growth }\end{array}$ & $\begin{array}{c}\text { Real } \\
\text { growth }\end{array}$ & & $\begin{array}{l}\text { Nominal } \\
\text { growth }\end{array}$ & $\begin{array}{c}\text { Real } \\
\text { growth }\end{array}$ & $\begin{array}{l}\% \text { of } \\
\text { GDP }\end{array}$ & $\begin{array}{c}\text { Nominal } \\
\text { growth }\end{array}$ & $\begin{array}{c}\text { Real } \\
\text { growth }\end{array}$ & $\begin{array}{l}\% \text { of } \\
\text { GDP }\end{array}$ & & \\
\hline 1980 & 44.5 & 16.2 & -3.0 & 36.1 & 9.5 & 21.6 & 26.2 & 1.5 & 18.6 & 5.2 & 28.7 \\
\hline 1981 & 36.1 & 16.0 & -4.3 & 34.3 & 14.4 & 23.0 & 27.0 & 8.2 & 18.8 & 4.5 & 21.4 \\
\hline 1982 & 37.0 & 29.1 & -3.9 & 8.3 & 2.0 & 21.7 & 9.0 & 2.6 & 17.8 & 4.4 & 7.2 \\
\hline 1983 & 22.9 & 17.2 & -1.4 & 2.0 & -2.7 & 18.8 & 15.1 & 9.7 & 17.4 & 4.1 & 3.4 \\
\hline 1984 & 19.0 & 13.9 & -1.2 & 11.3 & 6.5 & 18.2 & 12.5 & 7.7 & 17.0 & 3.8 & 2.3 \\
\hline 1985 & 18.1 & 13.3 & -0.8 & 9.0 & 4.6 & 17.8 & 11.2 & 6.7 & 16.9 & 4.0 & 2.5 \\
\hline 1986 & 29.5 & 24.3 & -0.1 & 4.6 & 0.4 & 15.9 & 9.3 & 4.9 & 15.8 & 3.8 & 2.8 \\
\hline 1987 & 30.3 & 24.3 & 0.2 & 17.0 & 11.6 & 15.8 & 19.1 & 13.6 & 16.0 & 3.1 & 3.0 \\
\hline 1988 & 29.8 & 21.7 & 1.2 & 15.2 & 8.0 & 15.3 & 22.3 & 14.7 & 16.4 & 2.5 & 7.2 \\
\hline 1989 & 25.8 & 19.0 & -0.0 & 22.1 & 15.5 & 16.5 & 13.4 & 7.2 & 16.5 & 2.6 & 5.7 \\
\hline 1990 & 25.3 & 13.5 & -0.8 & 29.9 & 17.6 & 17.8 & 23.9 & 12.3 & 17.0 & 2.4 & 8.5 \\
\hline
\end{tabular}

\section{Financial Crisis and Restructuring (1997-2007)}

November 1997, the economic crisis started when domestic banks were rushed to withdraw from the loans international creditors. This drove the financial market into a serious state. It began when the Kia motor company faced nonpayment problem. The government applied a grace period also to Kia, but the deferment of non-payment of the Kia brought about credit crunch problems. Coupled with domestic difficulties, the currency crisis in the South East Asian region droves Korea into a dangerous situation. In response to these new environments, the Korean government asked for IMF's rescue with the credit of 59 billion Usd and controlled condition the economy policies agreement. They brought about drastic changes in governance structure, business strategies, business organization, and performance. However, global competitiveness was brought by a few pioneering firms. There were still deficiencies and weaknesses in the competitive advantage, governance structure, capacity and the global standard for the other Korean firms which would soon require improvement [3]. Major government economic policies as follow:

(*) Big Deal- swapping business among Chaebols.

(*) Workout program

(*) Improving the corporate financial structure

(*) Enhancing the corporate transparency and governance System

(*) Reform of Financial Institution and Privatization of Public Enterprises

(*) Nurturing Venture Business

\subsection{Big Deal and Restructuring Chaebols}

The government-directed central system brought about regulation-oriented bureaucracy and Chaebol-oriented industrial policies. Such operation created close government-business nexus, breach of discipline, expansion of corruption. Many firms did not have a transparent accounting system. Also, the government intervened in the banking sector and abused the authorization for permission, licensing and certifying in investment for the R\&D and human capital sector. In 1998, the government and the owners of the 4 largest Chaebols agreed on: first, enhancing the transparency of corporate management; second, eliminating cross-debt guarantees; third, improving capital structures; fourth, focusing on core businesses and strengthening the cooperation with small to medium enterprise (SME); fifth, raising the mission of controlling shareholders and managers. The big five Chaebols were strongly urged to a big-deal focus on the core industry so that each one of them could lead streamlining business activities from that point. The government encouraged the out-of-court settlements for the firm that were expected to recover. Hence, companies and creditors bargained rearranging or 
restructuring with more flexibility than informal proceedings. The Chaebol that survived were urged to do their best for restructuring through the invitation of foreign investment, asset sales and consolidation of subsidiaries. [1], [4]

\subsection{New Business Environment}

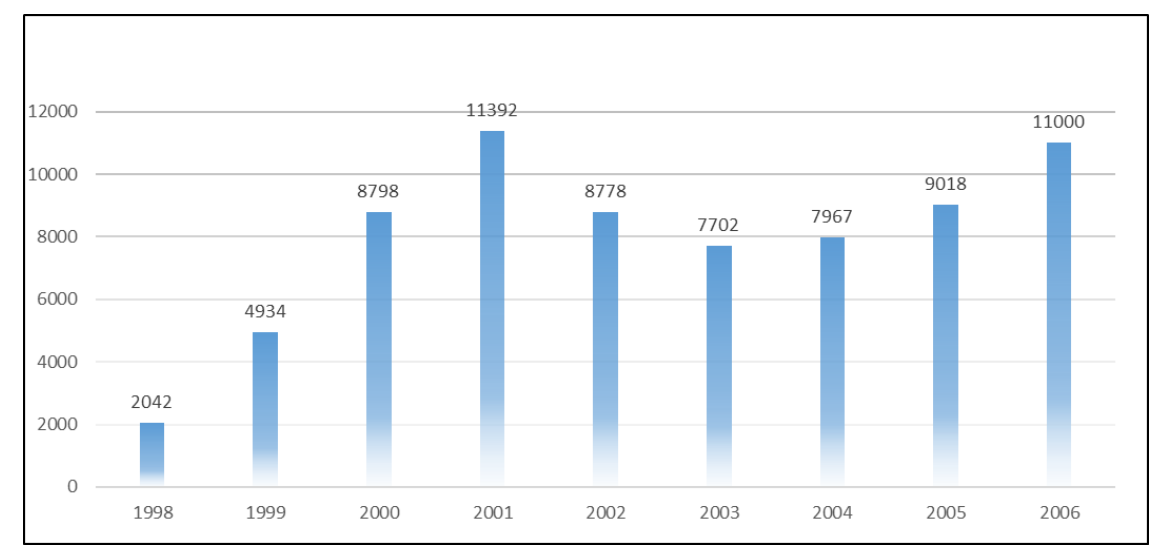

Figure 3. Number of Venture Business from 1998 - 2006

Corporate Finance and Governance Structure. The government established new accounting and auditing rule in line at the international level to intensify the reliability of corporate financial statements. The combined financial statements following international accounting principle were introduced. The corporate governance was strengthened through opening-up of M\&A market, complete resolution of cross-debt guarantees, and the limitation of the voting power of institutional investors. Further, voting rights of minority shareholder were strengthened. In addition, all companies were required to establish committees of external auditors and included external members of the executive director committee for the transparent decision-making process and elevated responsibility. [4]

Restructuring Financial Institutions and Public Enterprises. One of the causes of the crisis was the adoption of the overambitious open-door policy to join OECD members without prior preparation. Further, the government failed to supervise the financial institutions prudently due to capital liberalization policies. Many financial institutions including large bank were faced with insolvency. To minimize the moral hazard and maintain market discipline, the incumbent management of institutions was removed, and employees were laid off, existing shares were retired. The government rose restructuring funds of 104 trillion won in two rounds of bond issues and 168.3 trillion won from international lenders, state property holding and public funds. 327 financial institutions were liquidated, including ten commercial banks and twenty merchant banks. Many public enterprises were privatized to encourage private sector restructuring and to invite capital inflow. In 1998, a comprehensive privatization plan covered eleven big enterprises which aimed to complete transfer of control of the public enterprises to the private sector. Many infrastructure or utilities companies were included. [4]

\subsection{Shift to High Tech and Venture Business}

After the financial crisis, the growth of firms slowed down with declining profits. However, the Korean firms undertook decisive and drastic structural adjustment and management innovation. Regarding the recovery of world economy, China and Eastern Europe provided the breakthrough for the Korean economy. Traditional industries (automobile, shipping and steel) substantially contributed to the fast recovery of the Korean economy. The government made the Special Act for Nurturing Venture Business 
in 1997. The government provided all the necessary incentives, including financial support and procurement of human resource to SME-led venture business. Many scholars who had worked in the large scale companies, rushed to create the venture business. The number of venture business was 2,000 in 1998 and 11,000 in 2001. Then it reduced after that and recovered in 2006. In 2003, the government started the ten next-generation growth locomotives to encourage innovation and entrepreneurship, which reflected the efforts directed toward the new business opportunities and future investment plan after the financial crisis. Korean companies sought a way out for their survival during the relevant period. Despite the shift to high-tech, other traditional companies enhance the competitive strength in the global market. These efforts made the fostering of globally competitive firms possible. [3], [4], [6]

\section{Chaebols and Their Contribution to the Success of Korea Economy}

There are some academic studies about the Korean economy and Korean companies, especially Chaebols. They mainly centered on the history, relationship between value and ownership structure, the gap between controlling power and cash flow ownership, evaluations of reformation policies about Chaebols and so forth. [2] So what is Chaebols? how did they contribute to Korean economic growth?

Chaebol is a business group of firms that is owned and run by family members or relatives in numerous business areas. It started to form as early as in the 1950s. It is characterized by ambitious, aggressive entrepreneurial orientation, paternalistic leadership, centralized planning, and coordination. Korean Chaebols formed a close relationship with the government with finance source mostly from government. The core business was established through the cheap acquisition of the confiscated enemy properties, exclusive allocation of foreign aid materials, acquisition of import licensing and quota, lower interest rates, the participation of government contract. [4]

Table 3. Profitability of Major Chaebols

\begin{tabular}{|c|c|c|c|c|c|}
\hline Chaebols & Finance criteria & 2002 & 2005 & 2008 & 2010 \\
\hline Samsung & $\begin{array}{l}\text { Revenues } \\
\text { Operation income } \\
\text { Net income } \\
\text { Margin }(\%)^{*} \\
\text { ROE }(\%)^{* *}\end{array}$ & $\begin{array}{c}118.94 \\
13.40 \\
9.66 \\
11.27 \\
23.90\end{array}$ & $\begin{array}{c}145.36 \\
11.35 \\
9.12 \\
7.81 \\
15.36\end{array}$ & $\begin{array}{c}206.08 \\
12.10 \\
9.42 \\
5.87 \\
11.10\end{array}$ & $\begin{array}{c}259.63 \\
29.14 \\
23.45 \\
11.22 \\
19.28\end{array}$ \\
\hline $\begin{array}{c}\text { Huyndai } \\
\text { Motor }\end{array}$ & $\begin{array}{l}\text { Revenues } \\
\text { Operation income } \\
\text { Net income } \\
\text { Margin }(\%)^{*} \\
\text { ROE }(\%)^{*}\end{array}$ & $\begin{array}{c}48.12 \\
3.13 \\
1.90 \\
6.50 \\
14.14\end{array}$ & $\begin{array}{c}58.83 \\
2.29 \\
2.82 \\
3.89 \\
14.36\end{array}$ & $\begin{array}{l}93.12 \\
5.23 \\
2.00 \\
5.62 \\
6.69\end{array}$ & $\begin{array}{c}131.25 \\
12.79 \\
10.13 \\
9.74 \\
22.39\end{array}$ \\
\hline SK & $\begin{array}{l}\text { Revenues } \\
\text { Operation income } \\
\text { Net income } \\
\text { Margin }(\%)^{*} \\
\operatorname{ROE}(\%)^{* *}\end{array}$ & $\begin{array}{c}43.40 \\
3.88 \\
-4.69 \\
8.94 \\
-68.37\end{array}$ & $\begin{array}{c}48,29 \\
4.86 \\
3.38 \\
10.06 \\
20,10\end{array}$ & $\begin{array}{l}88.8 \\
4.45 \\
1.74 \\
5.01 \\
7.03\end{array}$ & $\begin{array}{c}90.70 \\
5.2 \\
2.72 \\
5.73 \\
10.06\end{array}$ \\
\hline $\mathbf{L G}+\mathbf{G S}$ & $\begin{array}{l}\text { Revenues } \\
\text { Operation income } \\
\text { Net income } \\
\text { Margin }(\%)^{*} \\
\text { ROE }(\%)^{*}\end{array}$ & $\begin{array}{c}79.11 \\
4.69 \\
2.25 \\
5.93 \\
13.08\end{array}$ & $\begin{array}{c}91.08 \\
4.75 \\
3.13 \\
5.22 \\
12.37\end{array}$ & $\begin{array}{l}139.4 \\
8.55 \\
3.36 \\
6.13 \\
9.10\end{array}$ & $\begin{array}{c}154.07 \\
10.22 \\
7.20 \\
6.63 \\
16.41\end{array}$ \\
\hline LOTTE & $\begin{array}{l}\text { Revenues } \\
\text { Operation income } \\
\text { Net income } \\
\text { Margin }(\%)^{*} \\
\operatorname{ROE}(\%)^{* *}\end{array}$ & $\begin{array}{l}16.22 \\
1.19 \\
0.62 \\
7.34 \\
6.68\end{array}$ & $\begin{array}{c}24.49 \\
2.16 \\
1.27 \\
8.82 \\
10.57\end{array}$ & $\begin{array}{l}33.15 \\
1.70 \\
1.56 \\
5.13 \\
7.92\end{array}$ & $\begin{array}{c}47.35 \\
3.14 \\
1.63 \\
6.63 \\
5.19\end{array}$ \\
\hline
\end{tabular}

The history of the Chaebol's birth and growth can be expressed in five phases: The first phase (1945-1960), Chaebols were mostly launched in the 1950s, a capital-gaining term. Chaebols were able to obtain their capital with significant governmental support in promoting employment, and general stability. The second phase (1961-1971), Chaebols 
grew rapidly under government leadership oligopolies enjoying in most of the domestic market, encompassing light and heavy industry. They also had the benefit of favorable loans, the export-oriented support policies, and a growing local market. The third phase (1972-1979), Chaebols involved deeply in heavy, chemical industries and other fastgrowing industries, using favorable loans, combinations, and acquisitions, investments in real estate, and raise monopolization. The fourth phase (1980-1987), Chaebols concentrated on rising sales volume and new ventures with current partners in their groups. The manufacturing sectors grew significantly while they tried to increase their business in the financial area. The fifth phase (1988-2007), Chaebols actively involved in new ventures, such as supply chain management, information and communication technology and the appearance of "globalization". Meanwhile, they also heavily invested in the automotive industries and electronics, both internationally and domestically. They also focused upon growing high technology, building the brand and marketing channels, partly through investing in foreign companies.

Table 4. Ranking of Chaebols from 1987 to 2011

\begin{tabular}{|c|c|c|c|c|c|}
\hline Ranking & 1987 & 1999 & 2000 & 2004 & $2006-2011$ \\
\hline 1 & Huyndai & Huyndai & Samsung & Samsung & Samsung \\
2 & Daewoo & Samsung & Huyndai & LG & Huyndai-Motor \\
3 & LG & Daewoo & LG & Huyndai-Motor & SK \\
4 & Samsung & LG & SK & SK & LG \\
5 & Hanjin & SK & Huyndai-Auto & Hanjin & Lotte \\
\hline
\end{tabular}

In terms of general management and marketing, the characteristic of Chaebol can be summarized as: Leadership, combining strong leadership and an entrepreneurial orientation. Structure control, family control and management, concentrated plan and organizational vertical structure; paternalistic relationships. Strategy-longevity, development through a long-term orientation and diversification, long-term relationships and strong work moral. Partnership, the government, supporter, developer were partners in an entrepreneurial orientation. Decision making, centralized resources, located by quick decision-making and coordination. Social exchange, the important of personal relationships, social contacts and team harmony are emphasized. [5]

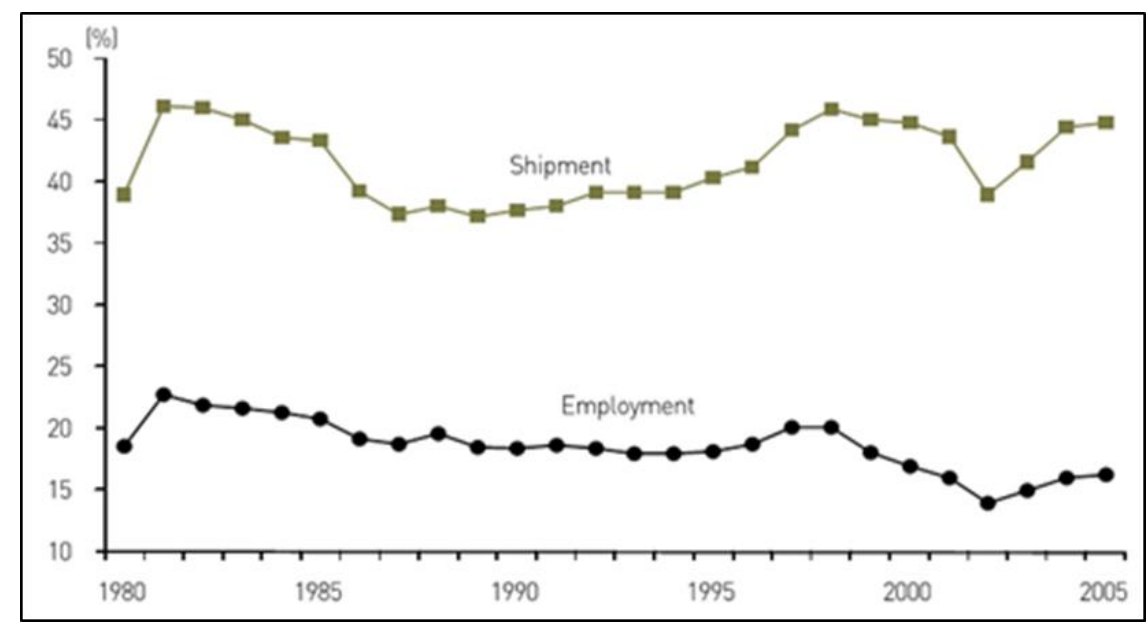

\section{Figure 4. Portion of the Biggest 100 Firms in Mining and Manufacturing}

The fast growth of exports and the birth of such new industries diversified the expansion path of big business in the 1960s. In the 1970s, the economic concentration by the Chaebols reached its peak when the HCI policy was driven intensively. Large business in Korea was able to grow into Chaebol, which had various businesses under a single control tower. They tried to expand their sizes without minding overlapping 
investments in one industry and whenever they were in danger of bankruptcy, they asked for the government's financial support. This action definitely weakened their competitiveness, increased the debt to equity ratio, lowered the owned capital ratio and in the long term, this led to the insolvency problem of financial institutions. They became a serious intimidation to fair competition between subsidiaries of the Chaebols, nonsubsidiaries, small and medium size businesses. Briefly, behaving in an oligopolistic way, the economy was skewed to favor their interests and impede free competition. In Korea's economy, the weight of the Chaebols is significantly high. The scale of their properties was $35.1 \%$ of GDP in 1992; it increased to $60.3 \%$ in 1998 with growths of $25.2 \%$ points for six years. The scale of five vital Chaebols' properties was $32.8 \%$ GDP in 2002, the lowest level since the financial crisis. Afterward, it systematically rose to $48.6 \%$ in 2010 with growth rate of $15.8 \%$ points for eight years. The systematical growth was remarkable, although the level was not as high as in the time of the financial crisis. Nevertheless, the number of Chaebols' affiliates is currently much greater. [4]

The public attention was attracted again after the financial crisis by the convergence of economic power. Notwithstanding, the cause for this recent attention was different. Despite the fact that the business performance of them was great, their contributions seem to be smaller than in the past. There are two opposing opinions. From the positive, Chaebols are a central component of Korean economic growth and a hero of Korean exports. High-tech brands are symbols of the high status of Korea over the world. Despite the global economic recession beginning in 2007, their high competitiveness in the global markets resulted in permanent export increases and economic growth. However, from the opposite view, with the monopoly ability, Chaebols force small and medium sized companies to make unfair deals with them. Furthermore, they rapaciously enlarge their business to small-scale areas through their superior capital power. The convergence of economic power driven by Chaebols is a symbol for the increased revenue discrepancy between the people classes in Korea. [1]

\section{Conclusion}

This study presents the outstanding post-war development of the Korean economy with an exceptional focus upon the role played by Korean companies. It is motivated by the extraordinary achievement of Korean economy and Korean companies. Therefore, there are many managerial implications for the developing countries concerning national and enterprise view, in particular for the Asian countries.

Regarding the national managerial implications, Korea has achieved not only huge economic growth but also wide-base social development in the last sixty years. In general, the role of the government in the Korea economic development is demonstrated. Government policies have been in line with market principles, especially regarding exchange rate and trade policies. Korea concentrated its endeavors on fostering economic growth.

The Korea government employed various market interventions including export promotion, the HCI drive, financial support, the bail-out of private companies, and price control. Notably, the private sector was encouraged to seek activities toward positive-sum productive activities from zero-sum by the strong political leadership. Besides, the right policies encompassed firmly established private property rights, focusing on education, a relatively stable macroeconomic environment, and infrastructure investment. Some of the interventions, especially infrastructure investment, export promotion, and education, successfully dealt with market failures and contributed to the economic growth. Furthermore, in the wake of the financial crisis, the Korean government restructured the corporate and fiscal sector and installed a free market system with institutional reforms. The Korea government strengthened prudential regulation, corporate governance, and the social safety network.

In the industrialization process, the Korean Government made international trade policies which have made an especially significant contribution to total factor productivity 
(TFP) growth. Global trade stimulated innovation, technology, and promoted the reallocation of resources from less to more productive sectors. The external economic policies also are developed in various areas such as trade, foreign investment, industrial corporation, agriculture, services and financial markets. In the 1960s and thereafter, a major contribution by the Korean government to the export development lay in removing market distortions created by protectionism and overvaluation.

Base on the foregoing, the Korean economy development provides many interesting and useful managerial implication for the developing countries, especially in making developed country policies. First, the market-led growth principle should be firmly established; the government interventions should be focused on the important industry, services and finance; supporting for SME should be concentrated on startup companies; the market competitive strengthen should be improved. Second, the private sector should be encouraged to develop by realistic policies including tax policy, capital support, technology, employee training. It is should be kept in mind that private sector is the main factor in national economic growth. Third, it is important to control and minimize macroeconomic risks by remaining low inflation, financial stability improvement, and ensuring fiscal sustainability. The economic policies should be directed at strengthening market mechanisms and pursuing consistently external liberalization in all areas. Furthermore, the government should actively promote the fair competition between producers, regulate monopolies, speed up market opening, and protect consumer.

Regarding the enterprise managerial implications, this study assesses the Korean companies, especially Chaebols by analyzing the developed history, characteristics, profitability, ranking in the domestic economic, portion and their contribution to Korea economic growth. The Korean companies, especially Chaebols proved robust competitiveness in the global markets and had been the primary benefit from growth as well as the driving force of the economic success. The growth of national economy with Chaebols' huge contribution has become a symbol. They achieved remarkable success because they were born from the real needs of the Korean economy with clear goals, firmly implemented policies. A key factor in the success of the Korean firms was the close relationship with government. Besides, there was a significant association between the characteristics of Korean companies with their successful.

The potential for such an expected way of progressing the business might exist in some diverse approaches. Therefore, the Korean companies, in particular Chaebols themselves still have some drawbacks. But overally, they have some valuable lessons to be learned for the developing country companies or western companies. First, the closed relationship with the Korean Government is an important factor in Chaebol's success. They can get their capital with substantial governmental support, encouraging business and general stability. Second, Chaebols have determined clearly objective, and growth pattern with specific practical solution. Third, Chaebols are very dynamic in finding the external resource, technology, and leverage the support from the government. Fourth, Chaebols especially focus on the employee training activity, establishing the center for training the high-quality employees. Besides, they have been the sponsors in the University to attract the best students who will ready become their staffs after graduation. It is a good way to building the high quality human resource. Fifth, Chaebols also concentrate on growing high technology, brand building and establishing marketing channels, partly through obtaining or investing in foreign companies. Sixth, Chaebols use communicating channel with news, television and so forth as a good way to attract, and to share their information with the public, and building the good relationship with stakeholders. Finally, Chaebols have been seeking cooperative relations in technology and financial support to upgrade the supply chain concerning higher quality, technology, and more consistent products. The merger of higher quality, social exchange, lower cost products with linkages to a basis of decision- making manifests to be a potent mix for worldwide business, including developing countries. 


\section{Acknowledgments}

This paper is a revised and expanded version of a paper entitled 60 Years of Korean Companies: How did they contribute to the Miracle of the Han River? (1945-2007) presented at the $4^{\text {th }}$ international conference on Smart media and Applications, Da Nang, 11-13 Jan, 2016.

\section{References}

[1] D. W. Nam, "Korea's Economic Growth in a Changing World" Samsung Economic Research Institute, (1997).

[2] D. Sig Choi, P. Michell, \& D. Palihawadana, "Exploring the components of success for the Korean chaebols", Journal of Business \& Industrial Marketing, vol. 23, no. 5, (2008), pp. 311-322.

[3] I. SaKong, \& Y. Koh, Editor, "The Korean Economy Six decades of growth and development" (2010).

[4] K. Kim , "Chaebols and Their Effect on Economic Growth in South Korea", Korean Social Sciences Review., vol. 3, no. 2, (2013), 1.

[5] S. S. Kim, "Korea's globalization", Cambridge University Press, (2000).

[6] T. Y. J. Shim, Editor, "Korean Entrepreneurship: The Foundation of the Korean Economy", Palgrave Macmillan, (2010).
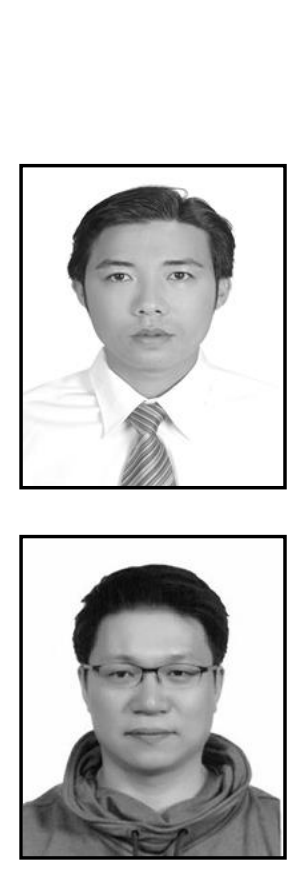

\section{Authors}

Phuoc Cuu Long Le, Ph.D. candidate in Marketing Department, College of Business, Soongsil University, Seoul, Korea. He is a faculty of Marketing Department, Vietnam-Korea Friendship information technology College. His interest and recent works are Marketing Research, New product development and Idea generation.

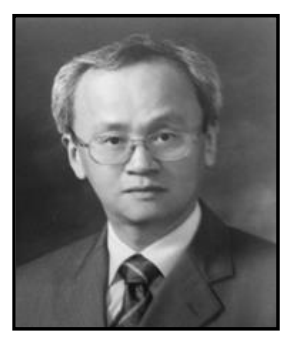

Jong Ik Kim, Ph.D. candidate in Marketing Department, College of Business, Soongsil University, Seoul, Korea. He is CEO of SEHWA HITECH Co.Ltd. Korea \& K-Solutions Limited, Hong Kong. His interest and recent works are Creative idea generation and Startup company consulting.

Kunbae Kim is professor of Marketing Department, College of Business, Soongsil University, Seoul, Korea. He is also a senior consultant of CJ, Lotte, LG, Samsung Corporation. His interest and recent works are in New product development, Concept creation, Marketing Research, Concept Engineering and Advertising. 